\title{
SELMA: tutkimassa kokemuksen, kertomuksen ja muistin kytköksiä
}

Hanna Meretoja 
onitieteinen tutkimuskeskus SELMA tarkastelee kertomista, M kokemuksellisuutta ja muistamista kulttuurisina ilmiöinä ja keskittyy niiden välisiin kytköksiin. Se tuo yhteen eri alojen tutkijoita ja pyrkii edistämään tieteiden ja taiteiden välistä vuoropuhelua.

Kokemuksen, kertomuksen ja muistin välisiä suhteita koskevalla tutkimuksella on pitkä perinne Turun yliopiston Historian, kulttuurin ja taiteiden tutkimuksen laitoksella. Pitkäaikaiset suunnitelmat tutkimuskeskuksen perustamisesta realisoituivat kesäkuussa 2015, jolloin johtamani Emil Aaltosen projekti ("Historian kokemus ja kertomisen etiikka nykytaiteissa", 2013-2015) järjesti Turussa kansainvälisen päätöskonferenssinsa, "Ethics of Storytelling: Historical Imagination in Contemporary Literature, Media and Visual Arts", ja sen yhteydessä julkistimme uuden tutkimuskeskuksen, SELMA: Centre for the Study of Storytelling, Experientiality and Memory. Vedän keskusta yhdessä sen varajohtajan, kulttuurihistorian yliopistonlehtori Maarit Leskelä-Kärjen kanssa, apunamme monialainen johtoryhmä, kansainvälinen ohjausryhmä ja koordinaattorina toimiva postdoc-tutkija - parhaillaan Nena Močnik, jatkossa Marta Cenedese.

SELMA on monitieteinen tutkimuskeskus, joka keskittyy tarinankerronnan, kokemuksellisuuden ja kulttuurisen muistin välisten kytkösten tarkasteluun erilaisista teoreettisista ja historiallisista näkökulmista. Keskeisiin tutkimuskohteisiimme kuuluvat kerronnallinen toimijuus, elämän tarinallistaminen, elämäkerrallisuuden ja omaelämäkerrallisuuden eri muodot, kulttuuristen kertomusten hyödyt ja haitat, traumakertomukset, sotaan, väkivaltaan ja muuttoliikkeeseen liittyvät kertomisen ja muistamisen prosessit, eri taidemuotojen kehittämät kerronnalliset strategiat ja niiden eettinen potentiaali, muistamisen ylirajaisuus, digitaalinen tarinankerronta sekä kulttuurinen hyvinvointi ja siihen kytkeytyvät keskustelut. Olemme järjestäneet kertomuksen, kokemuksen ja muistin käsitteisiin keskittyviä tutkimustapahtumia, käsitetyöpajoja ja lukupiiritoimintaa, kansainvälisiä konferensseja ja symposiumeja sekä kaikille avoimia yleisötilaisuuksia ajankohtaisista yhteiskunnallisista aiheista, kuten pakolaiskriisistä ja brexitistä. Meitä kiinnostavat kertominen, kokeminen ja muistaminen kulttuurisesti välittyneinä, historiallisesti muuttuvina ja eettispoliittisesti latautuneina ilmiöinä.

Keskuksen toiminnassa on mukana hyvin erilaisilta tieteenaloilta tulevia tutkijoita - kirjallisuudentutkijoiden lisäksi muun muassa visuaalisten taiteiden tutkijoita, musiikkitieteilijöitä, historiantutkijoita, digitaalisen kulttuurin ja kulttuuriperinnön tutkijoita, folkloristeja, uskontotieteilijöitä, kielitieteilijöitä, psykologeja, filosofeja, sosiologeja, poliittisen historian tutkijoita, kasvatus-, oikeus-, kauppa- ja hoitotieteilijöitä sekä tulevaisuudentutkijoita. Keskus 
linkittyy Turun yliopiston tutkimusstrategian temaattiseen kokonaisuuteen "kulttuurinen muisti ja yhteiskunnan muutos" ja kokoaa yhteen tämän alueen tutkimusta. Se on ainoa suomalainen kulttuurisen muistin tutkimuksen keskus; kertomuksen tutkimuksen keskuksena se on sisarkeskus tamperelaiselle Narrarelle, jota olin perustamassa vuotta ennen SELMA-keskusta ja jota nykyisin johtaa Maria Mäkelä.

Samanlaista kertomusten, kokemuksellisuuden ja muistamisen suhteisiin keskittyvää kokonaisuutta ei ole muualla maailmassa, ja SELMA onkin herättänyt paljon kansainvälistä kiinnostusta. Keskukseen on affilioitunut tutkijoita ympäri maailmaa, ja se on houkutellut ulkomaisia tutkijoita hakemaan tutkijapaikkoja muun muassa Turun ihmistieteellisestä tutkijakollegiumista (TIAS). SELMA-keskuksen ympärille onkin rakentunut aktiivinen kansainvälinen tutkimusverkosto. Verkostoa on osaltaan vahvistanut pohjoismaisen verkostorahoituksen saanut "Narrative and Memory: Ethics, Aesthetics, Politics" (2017-2019), jota kanssani vetää Eneken Laanes ja jonka kansainvälinen konferenssi "Uses and Abuses of Storytelling: Theorizing the Intersections of Narrative, Memory and Identity" järjestettiin helmikuussa 2019 Turussa.

SELMA tekee kansainvälistä yhteistyötä useiden kertomuksen ja muistin tutkimuksen verkostojen ja keskusten kanssa. Sen tärkeimmät kansainväliset partnerit ovat toistaiseksi olleet Centre for Narrative Research (University of East London), George and Irina Schaeffer Center for the Study of Genocide, Human Rights and Conflict Prevention (The American University of Paris), The Holocaust Research Institute (Royal Holloway), Centre for Life-Writing Research (King's College London) ja Centre for Life-Writing (University of Oxford). Näistä kahden ensimmäisen kanssa se järjesti toukokuussa vuonna 2018 kertomuksia ja etiikkaa käsittelevän symposiumin Lontoossa.

Keskusta perustaessamme halusimme luoda tutkimusympäristön, joka tukee monitieteisiä tutkimushankkeita. Tässä SELMA on onnistunut erinomaisesti: sen piirissä toimii tällä hetkellä useita suuria tutkimushankkeita, jotka tuovat yhteen erilaisia tutkimusperinteitä. Maarit Leskelä-Kärjen johtama, Koneen säätiön rahoittama "Uuden etsijät" -hanke luotaa suomalaisen esoteerisuuden kulttuurihistoriaa 1880-luvulta 1940-luvulle. Johtamani Suomen Akatemian hanke "Identiteettityö: kerronnallinen toimijuus, metanarratiivisuus ja kirjallisuusterapia" on osa konsortiota "Välineelliset kertomukset: tarinankerronnan rajat ja aikalaiskriittinen kertomusteoria" (PI Maria Mäkelä, TaY; PI Hanna Meretoja, TY; PI Merja Polvinen, HY), joka kehittää kertomuskriittistä ajattelua ja välineitä tarinankerronnan läpäisemien sosiaalisten ja tekstuaalisten ympäristöjen analysoimiseen. Turun osahanke keskittyy erityisesti kerronnallisen toimijuuden kysymyksiin sekä nykykirjallisuuden tarinakriittisyyteen. Se tarkastelee kertomusten erilaisia käyttötapoja ihmisten elämässä ja yhteiskunnallisessa todellisuudessa kriittisesti pohtivaa "metanarratiivista" 
nykykirjallisuutta ja mahdollisuuksia käyttää sitä uudenlaisen lukupiiritoiminnan lähtökohtana.

SELMA on onnistunut saamaan myös erittäin kilpailtua EU-rahoitusta. Euroopan komission European Remembrance -ohjelman rahoittama monitieteinen tutkimushanke "\#NeverAgain: Teaching Transmission of Trauma and Remembrance through Experiential Learning”, jota johdan yhdessä hankkeen koordinaattorin Nena Močnikin kanssa, tarkastelee kätkettyjä vihan ja alistamisen mekanismeja, jotka opitaan sukupolvelta toiselle siirtyvien traumojen ja niitä ylläpitävien, usein harmittomilta vaikuttavien arkielämän käytäntöjen välityksellä. Esimerkiksi suomalaista identiteettiä hallinnut kertomus "talvisodan hengestä" ja sisusta on kytköksissä haavoittuvaisuutta kätkevään pärjäämisen eetokseen ja "hiljaisuuden kulttuuriin", joka siirtää sukupolvelta toiselle käsittelemättä jääneitä traumoja. Hankkeen kumppanit Suomesta, Bosnia ja Herzegovinasta, Italiasta, Liettuasta, Puolasta, Romaniasta, Saksasta ja Tanskasta tuottavat neljä paikallisten tapahtumien rypästä omissa yhteisöissään kokeillakseen kokemuksellisen oppimisen työkaluja, jotka mahdollistavat ylisukupolvisesti siirtyvien kollektiivisten traumojen vahingollisten seurausten kokemuksellisen ymmärtämisen ja sen hahmottamisen, miten ne aiheuttavat nykypäivään ulottuvia vihan ja koston kierteitä.

SELMA pyrkii olemaan avoin, innostava ja helposti lähestyttävä toimija paitsi akateemisessa ympäristössä myös laajemmin yhteiskunnassa ja kulttuurissa. Keskuksen tavoitteena on edistää tieteiden ja taiteiden vuoropuhelua sekä toimia tutkijat, taiteilijat ja yliopiston ulkopuoliset tahot kokoavana yhteisönä. Tieteiden ja taiteiden dialogi on saanut keskuksen toiminnassa useita eri muotoja. Olemme esimerkiksi järjestäneet tilaisuuksia, joissa on käsitelty pakolaiskriisiä, turvapaikanhakijoiden tarinoita ja traumaattisista kokemuksista kirjoittamista yhdessä pakolaistaustaisten taiteilijoiden (erityisesti runoilijoiden ja elokuvaohjaajien) kanssa. Tyttöyden taiteellista muistamista on pohdittu muun muassa populaarimusiikin tekijöiden kanssa ja elämän tarinallistamista tieto- ja kaunokirjailijoiden kanssa. Tänä keväänä tutkimme Kolmas tila -teatterin kanssa, mitä on romanttinen mieli.

Kaiken kaikkiaan SELMA on tarjonnut perinteisistä akateemisista instituutioista poikkeavan, ei-hierarkkisen ja erilaiset toimijat yhteen saattavan intellektuaalisen kodin kasvavalle joukolle tutkijoita ja taiteilijoita. Selmalaisia yhdistää kokemus siitä, että on hedelmällistä tarkastella eri tieteenalojen välisen dialogin kautta, miten yksilöiden kokemukset muovautuvat tarinoiksi, miten kulttuuriset tarinamallit muovaavat kokemuksia, millaisten kerronnallisten käytäntöjen kautta rakennetaan jaettuja menneisyyksiä - ja kiistellään niistä - ja minkälainen kerronnallinen mielikuvitus ohjaa suuntautumistamme erilaisiin mahdollisiin tulevaisuuksiin. Toivotamme kaikki Avain-lehden lukijat lämpimästi tervetulleiksi osallistumaan keskuksen toimintaan. 


\section{Linkkejä}

https://selmacentre.wordpress.com/

https://instrumentalnarratives.wordpress.com/

https://againneveragain.eu/

https://uudenetsijat.com/

https://narrativeandmemory.com/

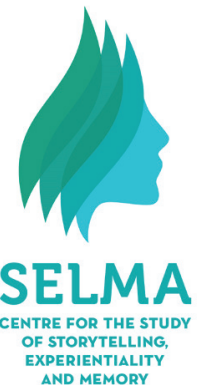

